\title{
Analysis of the Feasibility of \\ Generating Solid Biofuel from Ulex \\ Europaeus Plants
}

Alejandro Núñez-Moreno; Giacomo Barbieri; Gerardo Gordillo

Citation: A. Núñez-Moreno, G. Barbieri, G. Gordillo, "Analysis of the Feasibility of Generating Solid Biofuel from Ulex Europaeus Plants," Revista Facultad de Ingeniería, vol. 29 (54), e10454, 2020.

https://doi.org/10.19053/01211129.v29.n54.2020.10454

Received: August 01, 2019; Accepted: December 13, 2019;

Published: December 14, 2019

Copyright: This is an open access article distributed under the terms of the $\underline{\mathrm{CC} B Y}$

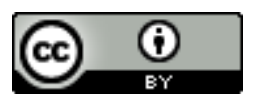

Competing interests: The authors have declared that no competing interests exist. 


\title{
Analysis of the Feasibility of
}

\section{Generating Solid Biofuel from Ulex Europaeus Plants}

\author{
Alejandro Núñez-Moreno ${ }^{1}$ \\ Giacomo Barbieri² \\ Gerardo Gordillo ${ }^{3}$
}

\section{Abstract}

The Ulex europaeus (also known as Common Gorse) represents a threat to the native ecosystems of different Colombian regions. Recently, the Ministry of the Environment and Sustainable Development introduced protocols for its prevention and management. Even though the Ulex europaeus has a high calorific value, a wide-spread solution for its post-processing is not yet available in its affected areas. In Colombia, the most common method for the disposal of the harvested plant is incineration, given that this is the suggested method by Resolution 684 of 2018. Due to the importance of the problem, this investigation is focused on studying the viability of creating solid biofuel alternatives derived from the plant. Grinded material and briquettes were produced with different log/foliage ratios in order to investigate both the domestic and industrial applications of the plant; e.g. heating, cooking and cogeneration, respectively. A proximate and ultimate analysis was performed on the produced samples. The generated solid biofuel presents $75 \%$ of the carbon heat value, a high volatile material content (83.3\%), and low ash and Sulphur residues ( $1.41 \%$ and $0.15 \%$ respectively). These results applied to both dry and humid samples, demonstrated that the produced solid biofuel is adequate for applications oriented towards heat generation. However, further analysis and process

\footnotetext{
1 Universidad de Los Andes (Bogotá-Distrito Capital, Colombia). a.nunez11@uniandes.edu.co. ORCID: 00000003-4787-5085.

2 Ph. D. Universidad de Los Andes (Bogotá-Distrito Capital, Colombia). g.barbieri@uniandes.edu.co. ORCID: 0000-0002-7051-2875.

${ }_{3}^{3}$ Universidad de Los Andes (Bogotá-Distrito Capital, Colombia).g.gordillo43@uniandes.edu.co.
} 
optimization is required in order to establish the generation of solid biofuel as an appropriate use of the Ulex europaeus remnants. By further analyzing the overall process; from plant removal, through residue disposal, and finally remnant conversion, the investigations value chain can be better established and possibly established for real world implementation.

Keywords: common gorse; energy; recycling; solid biofuel; Ulex europaeus.

\section{Análisis de factibilidad para la generación de biocombustible sólido a partir de la planta Ulex Europaeus}

\section{Resumen}

La planta Ulex Europaeus (Retamo espinoso) representa una amenaza para los ecosistemas de diferentes regiones en Colombia, lo cual llevó al Ministerio de Ambiente y Desarrollo Sostenible a definir una política que incentive la resolución a esta problemática además de protocolos para su contención y manejo. Debido a la relevancia que se le ha dado, esta investigación consiste en un primer estudio de viabilidad para la producción de biocombustible sólido a partir de la planta, que, aun teniendo propiedades caloríficas importantes, todavía no se tiene una respuesta definitiva sobre el uso y procesamiento de los residuos de la Ulex Europaeus. En este trabajo se hace énfasis, en la fabricación y evaluación de briquetas y mezclas de material molido con diferentes porcentajes tronco/follaje. Esto se hizo con el fin de fabricar biocombustible sólido en diferentes formas tanto para uso doméstico como industrial; p. ej. cogeneración. Las muestras producidas fueron sometidas a análisis próximo y último para la caracterización del producto generado. Los resultados demostraron que el biocombustible producido tiene un poder calorífico comparable con el del carbón ( $75 \%$ del carbón), un alto porcentaje de material volátil (83.3\%), y bajo contenido de ceniza y azufre ( $1.41 \%$ y $0.51 \%$ respectivamente). Esto aplica tanto para material seco como para el húmedo indicando que el biocombustible producido a partir de la planta parecería prometedor para aplicaciones de generación de calor. Sin embargo, se necesitan ulteriores análisis y optimizaciones del proceso antes de pensar en la generación de biocombustible sólido como una posible solución para el uso de los residuos de Ulex Europaeus. Al 
analizar todo el proceso más a fondo: desde la recolección de la planta in situ, pasando por la disposición del residuo final, y finalmente la conversión del material, se puede mejorar el entendimiento de la cadena de valor del mismo y buscar su implementación en el mundo real.

Palabras clave: biocombustible solido; energía; reciclaje; retamo espinoso; Ulex Europaeus.

\section{Análise de factibilidade para a geração de biocombustível sólido a partir da planta Ulex Europaeus}

\section{Resumo}

A planta Ulex Europaeus (Retamo espinhoso) representa uma ameaça para os ecossistemas de diferentes regiões na Colômbia, o qual levou o Ministério de Ambiente e Desenvolvimento Sustentável a definir uma política que incentive a resolução a esta problemática além de protocolos para sua contenção e manejo. Devido à relevância que se the tem dado, esta pesquisa consiste em um primeiro estudo de viabilidade para a produção de biocombustível sólido a partir da planta, que, ainda tendo propriedades caloríficas importantes, todavia não se tem uma resposta definitiva sobre o uso e o processamento dos resíduos da Ulex Europaeus. Neste trabalho faz-se ênfase, na fabricação e avaliação de briquetes e misturas de material moído com diferentes porcentagens tronco/folhagem. Isto fez-se com o fim de fabricar biocombustível sólido em diferentes formas tanto para uso doméstico como industrial; p. ex. cogeração. As amostras produzidas foram submetidas a análise próxima e última para a caracterização do produto gerado. Os resultados demonstraram que o biocombustível produzido tem um poder calorífico comparável com o do carvão ( $75 \%$ do carvão), uma alta porcentagem de material volátil (83.3\%), e baixo conteúdo de cinza e enxofre ( $1.41 \%$ e $0.51 \%$ respectivamente). Isto aplica tanto para material seco como para o húmido indicando que o biocombustível produzido a partir da planta pareceria prometedor para aplicações de geração de calor. Porém, necessitam-se posteriores análises e optimizações do processo antes de pensar na geração de biocombustível sólido como uma possível solução para o uso dos resíduos de Ulex Europaeus. Ao analisar todo o processo mais a fundo: 
desde a coleta da planta in situ, passando pela disposição do resíduo final, e finalmente pela conversão do material, pode-se melhorar o entendimento da cadeia de valor do mesmo e buscar sua implementação no mundo real.

Palavras chave: biocombustível sólido; energia; reciclagem; retamo espinhoso; Ulex Europaeus. 


\section{INTRODUCTION}

Currently in Colombia, an increasing problematic caused by the invasive plant Ulex europaeus is becoming evident. This plant is one of the 100 most damaging invasive plants in the planet [1]. The species; due to its resilience, germination capacity in complex locations, elevated growth and reproduction rates due to spores, represents a threat to native Colombian ecosystems such as those found in the rural areas of Cundinamarca and Boyacá [2]. In 2018, the Ministry of Environment and Sustainable Development decreed that it was the involved departments' responsibility to search for efficient mechanisms to fight this problematic because besides being harmful to the environment, it is showing to be hazardous to the general wellbeing of the populations whose farmland and potable water are in contact, and are affected by, the common Gorse [3]. In the Ministry's resolution, control, gathering, mitigation and eradication methods for the previously mentioned plant are described. However, no alternatives for its disposal are proposed once the plant is cut, crushed and transported to its final destination. The resolution only considers the incineration of the organic waste in order to avoid leaving remains that may result in new sprouts. Likewise, it is possible that different alternatives that may have more benefit and a positive social impact are not being considered.

Like many other countries around the world, Colombia is facing a growing energetic and environmental crisis. Due to the approach that has been used as of today concerning environmental policies such as the preservation of ecosystems, reduction of environmental impact and investigation in renewable energy sources, every moment; it is becoming more difficult to depend solely on traditional methods to supply the country's energetic needs [4]. In addition to limitations that the hydrocarbon industry is suffering, for example the prohibition of "fracking", it is foreseen that the country is going to have a decrease in investments intended for exploration, resulting in an increase in the price of fuel. Consequentially, it is expected that the productive potential of petroleum in the country decreases [5]. Considering this, it is important to revise which alternatives can be proposed in order

to obtain new fuel options, using the available resources that are present in Colombia. 
Previous studies about common Gorse (Ulex europaeus) have shown that it possesses usable properties in the energetic scope [6, 7]. After conducting thermo gravimetry tests, Lizarazo [6] evidenced that, due to the elemental compositions, the material contains a high carbon percentage that is viable for fuel purposes. Additionally, Osorio [7] added information to Lizarazo's investigations. Beyond corroborating the elemental composition, Osorio offered an approximation to the plant's heat value and the composition of the essential oils that might explain the Gorse's flammability; these investigations yield a better concept of the unique properties that the plant possesses. These studies, besides being supported by the analyses executed by Milquez- Sanabria [8], generated a deeper concept around the usefulness of the Gorse, and presented evidence of how this plant may become an opportunity, instead of a threat.

Based on the presented context, this article investigates the viability of producing a solid biofuel for industrial and domestic consumption, with the purpose of providing support to the advantages that will arise when the common Gorse becomes an energetic harvest. The article is structured in the following way: in section 2 the methods and materials are illustrated, in section 3 the results are described, section 4 contains result discussions and in section 5 the conclusions and approach towards future projects are established.

\section{MethodS}

The process that was executed during the investigation consisted in analyzing an alternative for integral benefit using the Ulex europaeus; in other words, from the gathering process to the final product delivery. The geographical areas in which the sampling would take place were established in the mountain path near Tausa (Cundinamarca) because of the availability of the Gorse in said area. However, the same investigation could be conducted in other geographical areas in future opportunities in order to compare results and establish if they can be replicated independent of the geographical precedence of the plant.

Figure 1 shows the sequence of stages proposed for the attainment of solid biofuel. It is notable that this project investigates the generation of two products: ground plant 
and briquettes. The project is based on the hypothesis that the shape of the first product may be useful for industrial consumption, and the second one for domestic use. The proposed stages are:

1) Gathering. Following the protocols proposed by Resolution 684 to avoid propagation [3].

2) Shredding and Packaging. In a possible future scenario for the utilization of the plant, the material must be transported from the fields to a processing center. For this reason, the shredding process is suggested, it generates a volume reduction, it decreases probability of seed propagation and decreases transportation fees.

3) Grinding. Necessary for the homogenization and consequentially, ease the blending and material extrusion.

4) Blending. Reintegration process of the different parts of which the Gorse is composed. This, with the objective of obtaining an initial approach of the log/foliage percentages that generate the most added benefit.

5) Extrusion. For the generation of briquettes. However, in future opportunities other mechanical processes that require a smaller energetic investment may be evaluated. An additional drying stage was observed during the process between the shredding and grinding stages that generates efficiencies during grinding. However, a detailed study about its effect is recommended for future projects.

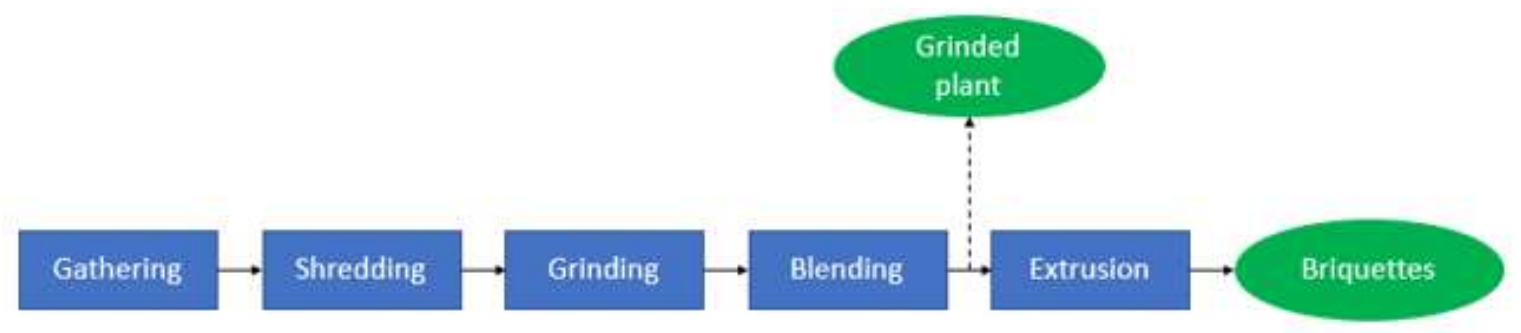

Fig. 1. Stages proposed for the utilization of the Ulex Europaeus as a solid biofuel.

\section{A. Experimental Methodology}

In this section, the steps implemented for the investigation of the attainment of solid biofuel made from the plant Ulex europaeus are illustrated. The main objective of the project is to define a log/foliage percentage that allows the establishment of a 
satisfactory balance between the heat value of the product and the best possible use of the plant.

For this, the first step was the characterization of the log/foliage percentage of the Gorse from Tausa. Following this, samples of the ground material with different log/foliage percentage were generated. Finally, some of these samples were extruded for the generation of briquettes. The following is the experimental methodology in detail:

1) Gathering of the Ulex europaeus Samples. 10 samples of the Gorse were gathered following the protocol established in Resolution 684 [3].

2) Separation of the Log and Foliage. The foliage was separated (thorns, leaves, seeds and fruit) from the log of the Gorse for posterior weighing and characterization of weight distribution of the common Gorse from the Salitre de Tausa- Cundinamarca mountain path.

3) Shredding (Chipper). The log and the foliage were shredded separately and the approximate volume reduction reached was measured.

4) Characterization of the Log/Foliage Percentage. The gathered samples were weighed separately in order to determine de total weight percentage occupied by the log and the foliage.

5) Grinding (Blade Mill). The log and foliage were ground separately in order to homogenize and so, ease the blending and extrusion of the material.

6) Blending. Using a blender, the required quantities were blended until an adequate homogenous mix was obtained for the production of the solid biofuel. Samples containing different log/foliage percentages were generated.

7) Extrusion (Single Screw Extruder). Some of the samples were inserted in an extruder for the generation of briquettes.

8) Execution of Proximate and Ultimate Analysis. Characteristic samples were selected and sent to be analyzed in the laboratory, with the purpose of determining: elemental composition, heat value, volatile material, ash, Sulfur, fixed Carbon and humidity. This was done in order to understand the behavior of the resulting material and to be able to conclude if the material is adequate as a solid biofuel. 


\section{B. Sample Analysis}

In order to calculate the log/foliage percentage, the population was treated as a random variable and the random error theory was used [9].

$$
x=x_{P R O M} \pm \frac{3 * \sigma}{\sqrt{N}}(99.7 \%)
$$

where $\mathrm{N}$ is the number of samples analyzed, and $x_{\text {PROM }}$ and $\sigma$, the average and standard deviation, respectively.

The obtained results in the proximate and ultimate analyses are based on ASTM certification and were implemented with the following methods:

Proximate:

- Total Humidity: ASTM D3302/D3302M-15

- Ashes: ASTM D3174-12

- Volatile Material: ASTM D3175-17

- Fixed Carbon: ASTM D3172-13

- Sulfur Content: ASTM D4239-17 Method A

- Net Heat Value: ASTM D5865-13

Últimate:

- Humidity: ASTM D3173-11

- Ashes Weight \%: ASTM D3174-12

- Total Sulfur Weight \%: ASTM D4239-14e2 Method A

- Total Carbon Weight \%: ASTM D5373-14

- Total Hhydrogen Weight \%: ASTM D5373-14

- Nitrogen Weight \%: ASTM D5373-14

- Oxygen Weight \%: ASTM D3176-09 (by diff)

\section{Implementation of the Experimental Methodology}

As per indicated in Resolution 684 [3], the Gorse requires careful handling since it's fruit tends to expel seeds by means of spore propagation (plant ejection) once it reaches maturity. This implies that the plant must be packed in situ, because any means of transportation will only foster the plant's seed propagation. 
Taking this into account, the chipper used (Figure 2), counted on superior safeguards on the inlet shaft and with a direct exit towards the packing, in order to avoid undesired propagation at the moment of the plant's shredding.

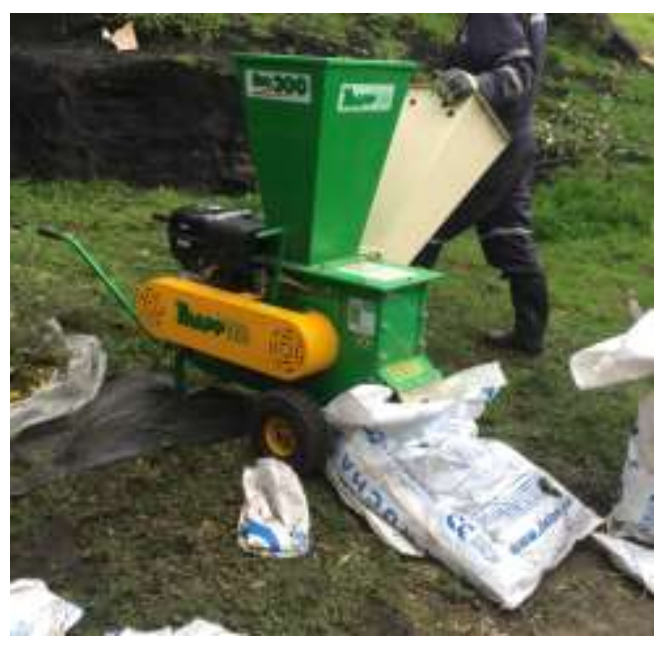

Fig. 2. "Trapp 300" Comertial chipper, used to shred and pack the samples in situ.

Once the samples were obtained, the material was ground in order to blend the required proportions. As can be observed in Table 1, the samples consisted of different log/foliage percentages and in both simple ground product and briquettes generated after an extrusion process. This with the objective of investigating the domestic and industrial alternatives. Finally, different compositions were evaluated so that a satisfactory balance between heat value and highest efficient plant use could be identified in at least one of them.

Table 1. Prepared and analyzed samples.

\begin{tabular}{|c|c|c|}
\hline Sample & Content & Type \\
\hline 1 & $100 \%$ Log & Briquette \\
\hline 2 & $60 \%$ Log $-40 \%$ Foliage & Briquette \\
\hline 3 & $60 \%$ Log $-40 \%$ Foliage & Ground Gorse \\
\hline 4 & $50 \%$ Log $-50 \%$ Foliage & Briquette \\
\hline 5 & $50 \%$ Log $-50 \%$ Foliage & Ground Gorse \\
\hline 6 & $50 \%$ Log $-50 \%$ Foliage $+15 \%$ Olive Oil & Briquette \\
\hline
\end{tabular}

Once blended, a sample of each composition was subject to an extrusion process. The extrusion process was selected since the synterization pressure and temperature had to be reached in order to produce the briquette [10]. Since the 
material was unknown, the extruder permitted the variation of the parameters in order to determine the optimum conditions for its manipulation.

In order to perform the extrusion process, the Brabender Plasti-Corder PLE 331 (Figure 3) machine was used and its temperature and pressure conditions were modified so that the level of compaction necessary for the material to maintain its shape after the process was executed was reached. It was found that, with a temperature of $80^{\circ} \mathrm{C}$ and a pressure of $900 \mathrm{psi}$, compact briquettes are obtained from samples that weren't subject to the drying process. Some of the samples obtained are presented in Figure 4.

Finally, the samples were sent to the CQR Cotecna laboratory for the proximate and ultimate analysis.

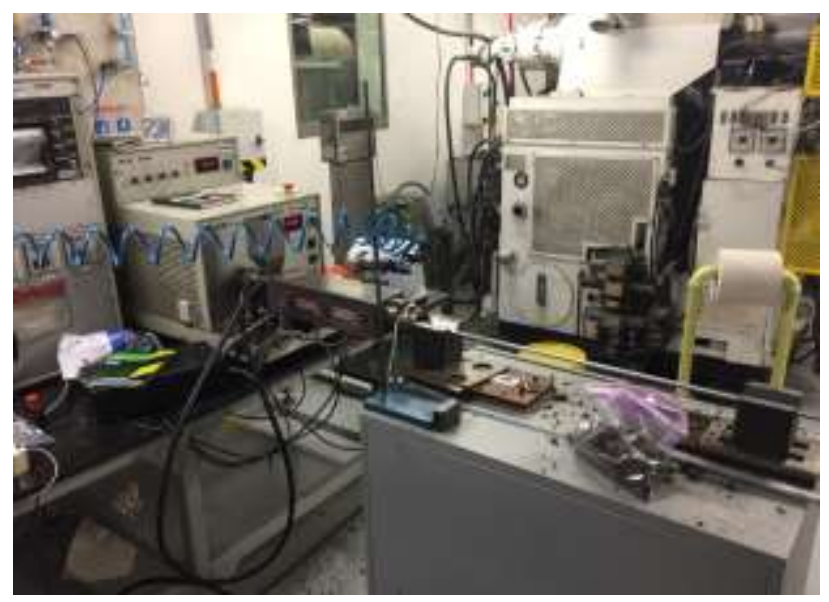

Fig. 3. Brabender PLE 331 Extruder.

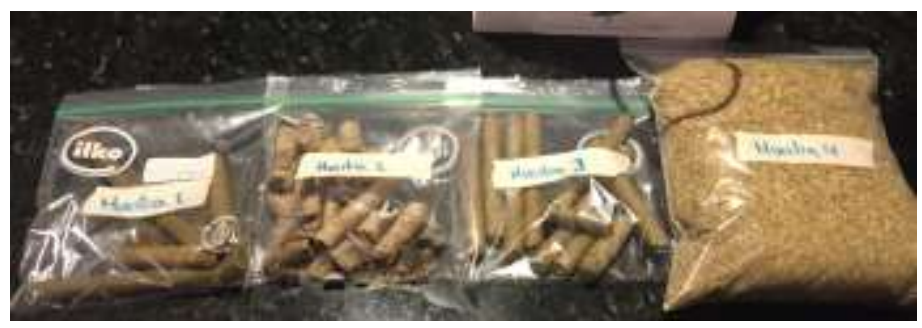

Fig. 4. Examples of extruded samples sent to the laboratory.

\section{RESULTS}

The obtained results are described in this section. 


\section{A. Volume Reduction}

It was estimated that the Gorse gathered occupied an approximate volume of $0.19 \mathrm{~m}^{3}$ $\left(187661 \mathrm{~cm}^{3}\right)$. This value was quantified based on the wheelbarrow used for the transportation of the material. Once the shredding process was finalized, the volume occupied by all the samples gathered was of $0.055 \mathrm{~m}^{3}\left(55000 \mathrm{~cm}^{3}\right)$. This value was obtained from the bag in which the samples were packed for transportation and handling. The volume reduction was calculated in the following way:

$$
\text { Volume Reduction }=\left(1-\frac{\text { Final Volume }}{\text { Initial Volume }}\right) \times 100=\left(1-\frac{55000 \mathrm{~cm}^{3}}{187661 \mathrm{~cm}^{3}}\right) \times 100=71 \%
$$

From the data obtained, there is evidence that once the material is shredded, the Gorse loses approximately $70 \%$ of its volume, allowing an efficient and easy transport. This is relevant to the study proposed due to the fact that it not only indicates the ease of material processing, but also the opportunity of cost reduction in transportation.

\section{B. Log/Foliage Percentage}

10 samples were analyzed in order to characterize the plants from de Salitre del Tausa mountain path, regarding the log/foliage percentage. The results are reported in Table 2.

Table 2. Results of weighing of gathered samples.

\begin{tabular}{|c|c|c|c|c|}
\hline Sample & Log (kg) & Foliage (kg) & Sample Weight & Log \% \\
\hline 1 & 1.7 & 1.7 & 3.4 & 50 \\
\hline 2 & 1.9 & 1.6 & 3.5 & 54 \\
\hline 3 & 2.2 & 1.9 & 4.1 & 54 \\
\hline 4 & 1.5 & 2.1 & 3.6 & 42 \\
\hline 5 & 1.7 & 1.4 & 3.1 & 55 \\
\hline 6 & 1.6 & 1.5 & 3.1 & 52 \\
\hline 7 & 2.1 & 2.0 & 4.1 & 51 \\
\hline 8 & 1.6 & 1.6 & 3.2 & 50 \\
\hline 9 & 1.7 & 1.8 & 3.5 & 49 \\
\hline 10 & 1.8 & 1.8 & 3.6 & 50 \\
\hline Average & 1.78 & 1.74 & 3.52 & 50.6 \\
\hline Total Weight & 17.8 & 17.4 & 35.2 & \\
\hline \multicolumn{7}{|r|}{}
\end{tabular}

Applying Equation 1 (random error) and finding the standard deviation of the weight, the following is obtained: 


$$
\begin{gathered}
\frac{3 * \sigma}{\sqrt{N}}(99.7 \%)=\text { random error } \log =\frac{3 \times 0.23}{\sqrt{10}}=0.218 \\
\frac{3 * \sigma}{\sqrt{N}}(99.7 \%)=\text { random error foliage }=\frac{3 \times 0.22}{\sqrt{10}}=0.209
\end{gathered}
$$

A range of weights can now be calculated, log:

$$
m_{\text {Log }}=(1.78 \pm 0.218) \mathrm{kg} \rightarrow(1.562-1.998) \mathrm{kg}
$$

And foliage:

$$
m_{\text {Foliage }}=(1.74 \pm 0.209) \mathrm{kg} \rightarrow(1.513-1.949) \mathrm{kg}
$$

\section{Proximate Analysis}

In order to evaluate the samples produced, proximate analyses were performed on all of the samples. Tables 3 and 4 report the results of the proximate analysis for the six samples prepared with humidity and dried, respectively. In Table 4, Carbon [11] and wood [12] values are added as a comparison. The numbers of the samples correspond to those described in Table 1.

Table 3. Results of the proximate analysis as received with humidity.

\begin{tabular}{|c|c|c|c|c|c|c|}
\hline Sample & $\begin{array}{c}\% \\
\text { Humidity }\end{array}$ & $\begin{array}{c}\% \\
\text { Ash }\end{array}$ & $\begin{array}{c}\text { \% Volatile } \\
\text { Material }\end{array}$ & $\begin{array}{c}\text { \% Fixed } \\
\text { Carbon }\end{array}$ & $\begin{array}{c}\% \\
\text { Sulfur }\end{array}$ & $\begin{array}{c}\text { Heat Value } \\
\text { (kJ/kg) }\end{array}$ \\
\hline $\mathbf{1}$ & 15.41 & 0.71 & 70.53 & 13.35 & 0.11 & 1614 \\
\hline $\mathbf{2}$ & 12.51 & 1.23 & 72.04 & 14.22 & 0.14 & 1878 \\
\hline $\mathbf{3}$ & 24.08 & 1.09 & 62.58 & 12.25 & 0.07 & 1490 \\
\hline $\mathbf{4}$ & 17.1 & 5.58 & 62.87 & 14.45 & 0.24 & 1594 \\
\hline $\mathbf{5}$ & 40.8 & 4.89 & 45.76 & 8.60 & 0.22 & 1229 \\
\hline $\mathbf{6}$ & 11.91 & 1.73 & 71.85 & 14.51 & 0.22 & 1938 \\
\hline
\end{tabular}

Table 4. Results of the proximate analysis Dry Basic without humidity.

\begin{tabular}{|c|c|c|c|c|c|}
\hline Sample & \% Ash & \% Volatile Material & \% Fixed Carbon & \% Sulfur & Heat Value (kJ/kg) \\
\hline $\mathbf{1}$ & 0.84 & 83.38 & 15.78 & 0.13 & 1908 \\
\hline $\mathbf{2}$ & 1.41 & 82.34 & 16.25 & 0.16 & 2146 \\
\hline $\mathbf{3}$ & 1.44 & 82.43 & 16.13 & 0.09 & 1962 \\
\hline $\mathbf{4}$ & 6.73 & 75.83 & 17.44 & 0.29 & 1923 \\
\hline $\mathbf{5}$ & 8.25 & 77.24 & 4.51 & 0.38 & 2073 \\
\hline $\mathbf{6}$ & 1.96 & 81.57 & 16.47 & 0.24 & 2251 \\
\hline Carbon & 18.27 & 43.44 & 30.69 & 0.82 & 3023 \\
\hline Wood & 3.38 & 80.87 & 12.68 & 0.42 & 1744 \\
\hline
\end{tabular}

\section{Ultimate Analysis 50:50 Sample}

The proximate analyses in the dry basic show values of heat value similar to those of the different samples. Because of this, it was decided to only evaluate sample 4 
in a detailed manner, through an ultimate analysis due to the fact that this allows the plant to be used completely. The results obtained in the analysis are reported in Table 5.

Table 5. Ultimate analysis results of sample 4 (Briquette $50 \%$ Log- 50\% Foliage).

\begin{tabular}{|c|c|c|c|c|c|c|c|}
\hline Sample & $\%$ Humidity & $\%$ Ash & $\% \mathbf{S}$ & $\% \mathbf{C}$ & $\% \mathbf{H}$ & $\% \mathbf{N}$ & $\% \mathbf{~ O}$ \\
\hline Type & AR & AR & AR & AR & AR & AR & AR \\
\hline $\mathbf{4}$ & 10.4 & 6.0 & 0.3 & 45.6 & 5.9 & 1.0 & 30.7 \\
\hline
\end{tabular}

\section{E. DAF Composition 50:50 Sample}

The Dry Ash Free (DAF) composition was calculated based con the results of the ultimate analysis, in order to be able to determine the chemical composition of the solid biofuel that was generated. For the calculations of the DAF, the following approximation was used, for Carbon:

$$
C_{D A F}=\frac{C_{A R}}{1-\text { Humidity }- \text { Ash }}=\frac{45.6}{1-0.104-0.06}=54.55 \%
$$

Applying the same procedure for the different elements, the following percentages were obtained and reported in Table 6:

Table 6. DAF Composition of Sample 4 (Briquette 50\% Log- 50\% Foliage).

\begin{tabular}{|c|c|c|c|c|c|}
\hline Sample & $\% \mathbf{S}$ & $\% \mathbf{C}$ & $\% \mathbf{H}$ & $\% \mathbf{N}$ & $\% \mathbf{~}$ \\
\hline Type & DAF & DAF & DAF & DAF & DAF \\
\hline $\mathbf{4}$ & 0.36 & 54.55 & 7.06 & 1.20 & 36.72 \\
\hline
\end{tabular}

From this percentage and the atomic mass, the number of moles present in the solid biofuel. The approximation, using Carbon as an example again, is reported as:

$$
N_{C}=\frac{C_{D A F}}{C_{P a}}=\frac{54.55}{12.0107}=4.54
$$

Applying the same procedure for the different elements, the following chemical composition is obtained:

$$
C_{4.54} S_{0.01} H_{7.00} N_{0.09} O_{2.3}
$$

\section{Discussions AND Conclusions}

The study executed came from the premise: "common Gorse possesses adequate properties for its use as a solid fuel, with purposes of low cost heat generation 
industrial and domestic scopes". In this section, the results are discussed in order to evaluate the premise mentioned.

In Table 3, the As Received (AR) results of the samples are shown. However, as the purpose of this study is to evaluate the properties of the material, Table 4: Dry Basic (DB) will also be taken into account.

When the obtained results were analyzed, it can be observed that, regarding ash (remaining material after the burning process), the best alternative is the product consisting solely of log. When more components are added to the product, it tends to leave more residue behind itself.

The volatile material, because of indicating the difficulty, or lack thereof, of combustion presented by the product, demonstrated that with or without foliage the material can be ignited.

In Figure 5 an example of material burning is presented, it lit on fire easily and managed to maintain a flame after being briefly exposed to a heat source.

The sulfur content is considerably low in all of the samples. The maximum being of $0.38 \%$ in the $50: 50$ ground Gorse sample.

Additionally, the fixed carbon content indicates de quantity of material of which the plant truly consists of, that can be exploited during combustion. In other words, it's the percentage of material that will maintain and generate heat. As can be observed in Table 4, the 50:50 in briquette form contains the most content of fixed carbon in comparison to all the other samples analyzed and it exceeds the value of common wood by a significant margin.

Finally, the heat value demonstrated that the material possesses important properties. Beyod the low emission of harmful products for human beings, and the few solid residues that are generated when burnt, the material truly shows competitive energetic characteristics. Kitchen carbon, considered one of the best current alternatives of biofuel leaves a considerable amount of residue and depends on little volatile material for its ignition; this implies more time and costs for its cleaning and implementation. When comparing the results obtained, the material, in its best result (60:40 in briquette form) reached a value close to $70 \%$ of the carbon heat value. When compared to the energetic potential of other materials [7] used as 
solid fuels, the Ulex europaeus plant demonstrates a significant potential for its use as biofuel (Table 7).

Table 7. Ultimate Alaysis Results (Briquette $50 \%$ Log - 50\% Foliage).

\begin{tabular}{|c|c|}
\hline Material & Heat Value (MJ/kg) \\
\hline Almond Skin & 36.80 \\
\hline Nut Shells & 32.00 \\
\hline Carbon & 30.23 \\
\hline Ulex Europaeus (60:40 DB) & 21.46 \\
\hline Comercial Briquettes & 20.93 \\
\hline Pine Bark & 20.40 \\
\hline Ulex Europaeus (50:50 DB) & 19.23 \\
\hline Corn Pellets [12-13] & 18.60 \\
\hline Wheat Peel & 15.80 \\
\hline Rice Peel & 15.30 \\
\hline
\end{tabular}

Many of the materials described in Table 7 belong to the most used solid biofuels today, However, the costs associated to their transformation, gathering and acquisition make them hardly viable for mass use and this leads to them being labeled as unimportant.

Because of everything mentioned previously, the sample that deserves a more detailed study, and that represents the best use of the problematic would be samples 4 and 5 . These use the material completely and without the need of additives such as oils. Besides, these samples count on the adequate characteristics for the generation of a solid biofuel for both domestic applications (after being synterized) and industrial use after its shredding and grinding.

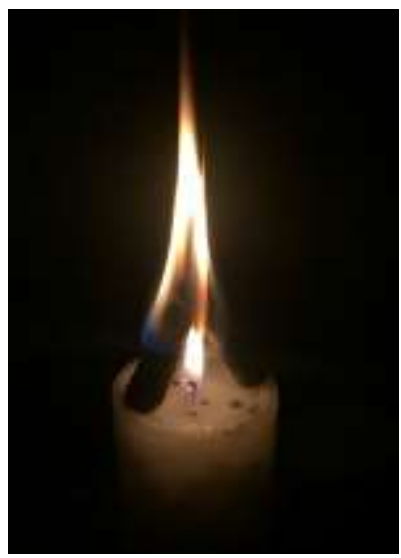

Fig. 5. Briquettes produced when being burned with a commercial candle. 
The process that was carried out, even if it requires optimization in order to generate products with even more competitive characteristics, gave a general vision of the potencial that common Gorse has as a solid fuel.

The conclusions based on the previous analysis are listed in the following page:

1. The shredding is an imperative step, given that it not only facilitates the grinding process, but it also reduces around $70 \%$ of the volume that the plan occupies in its natural state, and makes it easier to handle during gathering.

2. Even though the composition and properties don't vary greatly between the dry and wet samples, it is recommended to subject the gathered remains to a natural drying process. If optimum results are desired (fast and efficient drying process) an oven-based drying process can be implemented: Table 3 vs. Table 4.

3. Using the implemented procedures and all of the plant, without additives, competitive properties (as compared to common solid biofuels) were obtained.

4. The pressure and temperature parameters used in the generation of briquettes (900 psi and $80^{\circ} \mathrm{C}$ respectively) indicate that the process does not necessarily require heavy duty machinery such as the Brabender extruder. Given the findings, in future investigations it would be relevant to review several alternatives for the manufacturing of the briquettes. It is viable to base the initial trials in the studies carried out by Valderrama et al [14], when it comes to low cost manual methods for briquette manufacturing.

5. The feasability analysis provided an initial approach, to a possible process that would not only contain and avoid the random spread of Gorse, but also to create an opportunity to turn an environmental problematic into a $100 \%$ eco-friendly energy source.

6. The material can not only be used as briquettes, but also as ground material, and even pellet-like products [15]. Both ways demonstrate good heat generation properties; the only difference being the low production cost that the ground material would have over the briquette or pellet products 
7. Taking into account the previsouly mentioned, it is recomended to use the entire plant (50:50 log/foliage ratio) and through this, take advantage of all the biomass available. In addition, with optimized processess this biomass source could become a unique energy source because it makes use of an invasive species, reduces the need of cutting down native trees for domestic use and generates clean energy.

Expanding on the context provided by the used research sources throughout the investigation, along with the findings that resulted from the analysis, the Ulex europaeus plant would have the potential to be considered as an alternative energy source. Due to its growth and resiliance properties, and considering the potential energetic values discussed along the article, the Gorse could possibly become an energetic crop guided towards the generation of both domestic and even industrial heat. However, it is necessary to carry out further investigation before making a definitive statement that it is possible to turn an environmental problematic into an energetic opportunity with added benefit. Some suggestions would be: (i) calculate the efficiency of the process: energetic consumption required in order to produce the solid biofuel versus the generated heat value; (ii) evaluate more efficient briquette manufacturing methods; (iii) look into a fullstream process that includes logistics costs and region dynamics, in order to evaluate the financial feasability of the proposed solution; (iv) take into account the possible environmental impact of the project and establish a procedure that is both efficient and optimizes its carbon footprint.

\section{AUTHOR'S CONTRIBUTION}

Alejandro Núñez: Problematic proposition, context and state of the art investigation, sample gathering, sample processing, laboratory follow-up, analysis and discussion of the obtaine results, revision of the final document, document translation (from spanish to english). Giacomo Barbieri: Limiting of the problematic, guidance throughout the investigation, result processing techniques; final document revision. Gerdado Gordillo: Guidance in method implementation, as well as result analysis and discussion. 


\section{REFERENCES}

$\begin{array}{llllll}\text { [1] P. } & \text { Bingelli, } & \text { Woody } & \text { Plant } & \text { Ecology, } & 1997 .\end{array}$ https://members.lycos.co.uk/WoodyPlantEcology/docs/docs/websp18

[2] S. Lowe, M. Browne, S. Boudjelas, and M. De Poorter, 100 de las especies exóticas invasoras más dañinas del mundo. Una selección del Global Invasive Species Database, 2004. https://www.iucngisd.org/gisd/pdf/100Spanish.pdf

[3] Ministerio de Ambiente y Desarrollo Sostenible, Resolución 0684, 2018. http://www.minambiente.gov.co/images/normativa/app/resoluciones/5b-res\%20684\%20de\%202018.pdf

[4] S. Clavijo, "Desafíos del mercado energético de Colombia," La República, 2018. https://www.larepublica.co/analisis/sergio-clavijo-500041/desafios-del-mercado-energetico-de-colombia$\underline{2776774}$

[5] Redacción, "Sin fracking, el país tendría un dólar a 5.000 pesos: Ministra de Minas," El Heraldo, 2019. https://www.elheraldo.co/colombia/sin-fracking-el-pais-tendria-un-dolar-5000-pesos-ministra-de-minas$\underline{664461}$

[6] M. J. Lizarazo, Caracterización de Retamo Espinoso por Medio de Termo Gravimetría para uso Como Biocombustible, Graduate Thesis, Universidad de Los Andes, Bogotá, Colombia, 2017.

[7] D. F. Osorio, Análisis Estadístico de las Partes Funcionales de Ulex Europaeus Respecto a la Altitud y Caracterización del Retamo Espinoso (Ulex Europaeus) y Retamo Liso (Genista Monospessulana), Graduate Thesis, Universidad de Los Andes, Bogotá, Colombia, 2018.

[8] H. A. Milquez-Sanabria, "Production and Characterization of Activated Carbon of Gorse (Ulex Europaeus)," Publicaciones e Investigación, vol. 11 (2), pp. 89-97, 2017. https://doi.org/10.22490/25394088.2790

[9] J. Taylor, Introduction to error analysis, the study of uncertainties in physical measurements, 1997.

[10] J. I. G. Romero, Briquetas y Carbon - Las Briquetas más que un sustito de la leña, 2016. https://briquetasycarbon.com

[11] T. Onuegbu, I. Ogbu, N. Ilochi, U. Ekpunobi, and A. Ogbuagu, "Enhancing the Properties of Coal Briquette Using Spear Grass (Imperata Cylindrica)," Leonardo Journal of Sciences, vol. 17, pp. 47-58, 2010.

[12] Ministry of Agriculture, Proximate Analysis of Biofuels - Biomass Burn Characteristics, Ontario, 2019.

[13] N. Kaliyan, and R. Vance, "Natural binders and solid bridge type binding mechanisms in briquettes and pellets made from corn stover and switchgrass," Biorsource Technology, vol. 101 (3), pp. 1082-1090, 2010. https://doi.org/10.1016/i.biortech.2009.08.064

[14] A. Valderrama, H. Curo, C. Quispe, V. Llantoy, and J. Gallo, "Briquetas de residuos sólidos orgánicos como fuente de energia calorifica en cocinas no convencionales," in XVII CONIMERA, Lima, 2007.

[15] M. C. G. Garcia, Blusterpellet-Living Territoriweb, 2019. https://www.blusterpellet.com 